\title{
Evaluation of Genotoxic and Cytotoxic Effects in Human Peripheral Blood Lymphocytes Exposed In Vitro to Neonicotinoid Insecticides News
}

\author{
María Elena Calderón-Segura, ${ }^{1}$ Sandra Gómez-Arroyo, ${ }^{1}$ Rafael Villalobos-Pietrini, ${ }^{1}$ \\ Carmen Martínez-Valenzuela, ${ }^{2}$ Yolanda Carbajal-López, ${ }^{3}$ \\ María del Carmen Calderón-Ezquerro, ${ }^{1}$ Josefina Cortés-Eslava, ${ }^{1}$ Rocío García-Martínez, ${ }^{4}$ \\ Diana Flores-Ramírez, ${ }^{1}$ María Isabel Rodríguez-Romero, ${ }^{1}$ Patricia Méndez-Pérez, ${ }^{1}$ \\ and Enrique Bañuelos-Ruíz ${ }^{1}$ \\ ${ }^{1}$ Laboratorios de Citogenética y Mutagénesis Ambientales, Centro de Ciencias de la Atmósfera, Universidad Nacional \\ Autónoma de México, Ciudad Universitaria Coyoacán, 04510 México city, DF, Mexico \\ ${ }^{2}$ Departamento de Ciencias Biológicas, Universidad de Occidente, Boulevard Macario Gaxiola, Carretera Internacional, \\ Los Mochis, SIN, 81223 México, Mexico \\ ${ }^{3}$ Unidad Académica de Ciencias Químico Biológicas, Avenida Lázaro Cárdenas S/N, Universidad Autónoma de Guerrero, \\ Ciudad Universitaria, Chilpancingo, GRO, 39090 México, Mexico \\ ${ }^{4}$ Laboratorio de Química Atmosférica, Centro de Ciencias de la Atmósfera, Universidad Nacional Autónoma de México, \\ Ciudad Universitaria Coyoacán, 04510 México, Mexico
}

Correspondence should be addressed to María Elena Calderón-Segura, mcalderon@atmosfera.unam.mx

Received 17 June 2011; Revised 6 December 2011; Accepted 20 December 2011

Academic Editor: Brad Upham

Copyright (C) 2012 María Elena Calderón-Segura et al. This is an open access article distributed under the Creative Commons Attribution License, which permits unrestricted use, distribution, and reproduction in any medium, provided the original work is properly cited.

\begin{abstract}
Calypso (thiacloprid), Poncho (clothianidin), Gaucho (imidacloprid), and Jade (imidacloprid) are commercial neonicotinoid insecticides, a new class of agrochemicals in México. However, genotoxic and cytotoxic studies have not been performed. In the present study, human peripheral blood lymphocytes (PBL) were exposed in vitro to different concentrations of the four insecticides. The genotoxic and cytotoxic effects were evaluated using the alkaline comet and trypan blue dye exclusion assays. DNA damage was evaluated using two genotoxicity parameters: tail length and comet frequency. Exposure to $9.5 \times 10^{-6}$ to $5.7 \times 10^{-5} \mathrm{M}$ Jade; $2.8 \times 10^{-4}$ to $1.7 \times 10^{-3} \mathrm{M}$ Gaucho; $0.6 \times 10^{-1}$ to $1.4 \times 10^{-1} \mathrm{M}$ Calypso; $1.2 \times 10^{-1}$ to $9.5 \times 10^{-1} \mathrm{M}$ Poncho for $2 \mathrm{~h}$ induced a significant increase DNA damage with a concentration-dependent relationship. Jade was the most genotoxic of the four insecticides studied. Cytotoxicity was observed in cells exposed to $18 \times 10^{-3} \mathrm{M}$ Jade, $2.0 \times 10^{-3} \mathrm{M}$ Gaucho, $2.0 \times 10^{-1} \mathrm{M}$ Calypso, $1.07 \mathrm{M}$ Poncho, and cell death occurred at $30 \times 10^{-3} \mathrm{M}$ Jade, $3.3 \times 10^{-3} \mathrm{M}$ Gaucho, $2.8 \times 10^{-1} \mathrm{M}$ Calypso, and $1.42 \mathrm{M}$ Poncho. This study provides the first report of genotoxic and cytotoxic effects in PBL following in vitro exposure to commercial neonicotinoid insecticides.
\end{abstract}

\section{Introduction}

In 2008, Bayer CropScience México marketed a new class of agrochemicals, the neonicotinoids [1]. These insecticides are derivatives of nicotine and are classified as $\mathrm{N}$ nitroguanidines (imidacloprid, thiamethoxam, dinotefuran, and clothianidin) and N-cyano-aminides (acetamiprid and thiacloprid). These active components determine the insecticidal potency and selectivity of the insecticides [2].
A number of commercial formulations of neonicotinoid insecticides have been marketed. Poncho (active ingredient: clothianidin) is a systemic insecticide used to treat corn seeds against insects. Calypso 480 SC (active ingredient: thiacloprid) is applied to the foliage of cotton, apple, potatoes, and ornamental plants to control a number of insects. Two commercial formulations of imidacloprid are used: Gaucho $70 \mathrm{~S}$ is used to treat cucumber, pepper, squash, tomato, and tobacco pests, while Jade is used exclusively to 
control Aeneolamia postica in sugarcane crops [1]. These insecticides pose relatively little risk to nontarget organisms and the environment. Additionally, they have a high level of efficacy at low concentrations. As a result of these properties, neonicotinoid pesticides have begun replacing pyrethroids, chlorinated hydrocarbons, organophosphates, carbamates, and other insecticides [3].

Neonicotinoid insecticides are potent selective agonists of the nicotinic acetylcholine receptor (nAChR) in both invertebrates and vertebrates [4-6]. They are classified by the EPA [7] as class II [8,9] and III toxins and are labeled with a signal word: "Warning" or "Caution" [10]. Thiacloprid and thiamethoxam are likely human carcinogens [7-9]. In contrast, there is no evidence of carcinogenicity for imidacloprid and chlotiniadin [7-9]. Thiacloprid induces ovary tumors in mice [7-9] and uterine tumors in rats [7-9]. Thiamethoxam produces liver tumors in female and male mice [11, 12]. Imidacloprid and thiacloprid decrease reproduction rates in Caenorhabditis elegans and Eisenia fetida [13]. After metabolic activation in vitro (S9 enzymatic mix from rat livers), imidacloprid produces calf thymus DNA adducts [14], increases the frequency of spermatic abnormalities in Eisenia fetida [15], and is mutagenic in TA98 and TA100 Salmonella typhimurium strains, with or without S9 metabolic activation [16]. Imidacloprid also induces significant increases in the frequency of sister chromatid exchange and micronuclei formation in human peripheral blood lymphocytes $[17,18]$, mice and rat bone-marrow cells $[16,19]$, tadpole peripheral blood erythrocytes from Rana $N$-Hallowell [20], and Vicia faba roots [15]. Furthermore, imidacloprid causes DNA strand breaks in the coelomocytes of Eisenia fetida [15], tadpole erythrocytes from Rana NHallowell [20], human peripheral blood lymphocytes [17], and leukocytes in culture [18]. It does not cause DNA strand breaks in Vicia faba roots [21]. Acetamiprid is another insecticide that causes sister chromatid exchange, micronuclei formation, and chromosomal aberrations in human peripheral blood lymphocytes in vitro [22].

There are reports of neonicotinoid poisoning (imidacloprid and acetamiprid) in humans [23-27]. It is important to evaluate the genotoxic and cytotoxic actions of these new agricultural pesticides to contribute with toxicological data and regular use without polluting the environment and without leaving their residues in water and food sources with their possible risk on the organism health. But, in Mexico, there are no regulatory agencies on the pesticides safety requirements and lack of knowledge on appropriate protective measures and equipments by agricultural workers that could help them reduce the risk to exposure to agrochemicals.

Mexican agricultural workers are exposed to different pesticide mixtures, including organophosphates, organochlorines, carbamates, and pyrethroids, increase of the incidence of diseases and cancer. Differences in the exposure pathways to pesticides are responsible for variations in the tissue and organ distributions, patterns of biological effects, and toxic potency. The effects of exposure are dependent on diverse factors, including lifestyle, diet, state of chemoprotection, genetic predisposition or polymorphic expression of certain enzymes (e.g., CYP450s), and general health [28, 29].

Many studies have demonstrated that occupational exposure to pesticides induces DNA damage [30], such as sister chromatid exchange $[31,32]$, micronuclei formation [28, 33], chromosomal aberrations [34, 35], DNA adducts [36], and DNA strand breaks [37]. Numerous epidemiological studies have associated DNA damage with an increased incidence of functional alterations in the nervous [38], respiratory [39], reproductive [40], and immune systems $[41,42]$. DNA damage is also associated with an increased risk of cancer [41-46]. DNA lesions could be an initial event in the process of chemical carcinogenesis $[47,48]$, and the development of tumors may eventually occur [49]. In general, the induction of genotoxicity such as chromosomal and DNA lesions may lead to further problem of mutagenic and carcinogenic activity [49]. DNA damage is the under cause of mutations leading to cancer [47-49].

Considering that neonicotinoid insecticides are a new class of agrochemicals and there is lack of genotoxic studies on these pesticides, the present study aims to evaluate the genotoxic and cytotoxic effects of these chemicals. Human peripheral blood lymphocytes were exposed to Calypso (thiacloprid), Poncho (clothianidin), Gaucho, and Jade (both imidacloprid), and DNA damage was assessed using the alkaline comet and cell viability assays. The comet assay is a quick, simple, and sensitive method to detect DNA damage (single- and double-strand breaks, alkali-labile sites or DNA-DNA and DNA-protein crosslinks) induced by environmental chemical agents in individual cells, tissues, and organs [50, 51]. This assay has been proven to be reliable for the evaluation of genetic damage induced by agrochemicals both in vitro [52] and in vivo [37].

\section{Materials and Methods}

2.1. Chemicals. Hank's balanced salt solution, phosphate buffered saline, RPMI 1640 medium, normal-melting-point agarose, and penicillin/streptomycin were purchased from GIBCO, Ficoll-PaqueTM PLUS was obtained from GE Healthcare; low-melting-point agarose, trypan blue $(0.4 \%)$, ethidium bromide, Trizma Base, triton X-100 were purchased from Sigma-Aldrich, and ethylenedinitrilo-tetraacetic acid, and sodium hydroxide, sodium chloride were obtained from Baker.

\subsection{Preparation of the Neonicotinoid Insecticide Concentra-} tions. The neonicotinoid insecticides were donated by Bayer Cropscience (México) [1]. For the genotoxic and cytotoxic assays (Figure 1), Calypso 480 SC (\{(2Z)-3[(6-chloropyridin-3-yl)methyl]-1,3-thiazolidin-2-ylidene cyanamide; flowable suspension: thiacloprid, $480 \mathrm{~g}$ a.i./L; RSCO-INAC-0102T-301-064-040), Poncho (E-1-(2-chloro1,3-thiazol-5-ylmethyl)-3-methyl-2-nitroguanidine; RSCOINAC-103K-301-342-048; flowable suspension: clothianidin, $600 \mathrm{ga}$.i/L), and Gaucho 70WS (N-[1-[(6-chloro-3-pyridyl)methyl]-4,5-dihydroimidaclopriddazol-2-yl] nitramide; 


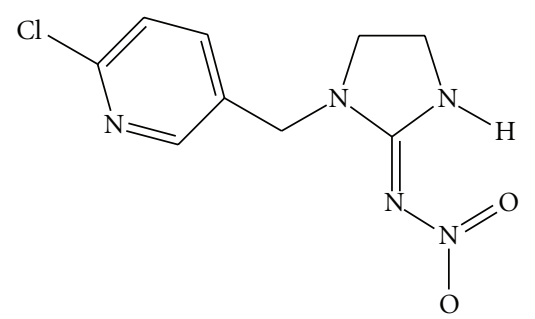

IMI<smiles></smiles>

THI

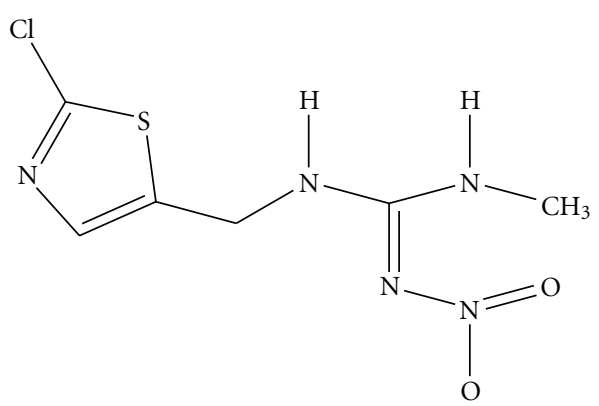

CLO

FIGURE 1: Chemical structures of imidacloprid (IMI), thiacloprid (THI) and clothianidin (CLO).

dispersible powder: imidacloprid, $700 \mathrm{~g}$ a.i./L; RSCO-INAC0199-305-034-070) were diluted 1:10 mL with deionized water, while Jade (granule: imidacloprid, $8 \mathrm{ga.i} / \mathrm{Kg}$ ) was diluted $3: 10$ in deionized water.

\subsection{Isolation of Lymphocytes from Human Peripheral Blood.} Twenty milliliters of heparinized venous blood obtained from three healthy volunteer donors was centrifuged at 2,500 rpm for $20 \mathrm{~min}$. The cellular layer was diluted $1: 1$ with HBSS, placed over a Ficoll-Paque layer, and centrifuged at $1,500 \mathrm{rpm}$ for $10 \mathrm{~min}$. Lymphocytes were collected and washed twice in RPMI 1640 medium by centrifugation at $1,500 \mathrm{rpm}$ for $10 \mathrm{~min}$. The lymphocyte pellet was kept in RPMI 1640 medium $\left(37^{\circ} \mathrm{C}\right)$ supplemented with $1 \%$ penicillin/streptomycin and immediately assessed for changes in cellular viability using a Neubauer chamber.

2.4. Cell Viability Test. Cell viability was estimated before and after treatments using the trypan blue exclusion method [53]. Trypan blue penetrates the damaged membrane of dead cells and stains the nucleus. A mix of $10 \mu \mathrm{L}$ of cell pellet and $10 \mu \mathrm{L}$ of trypan blue was incubated for $3 \mathrm{~min}$. Then the number of dead cells out of 100 consecutive cells was counted in duplicate.

2.5. Neonicotinoid Insecticide Treatment of Human Peripheral Blood Lymphocytes In Vitro. Human peripheral blood lymphocytes $\left(5 \times 10^{5}\right.$ cells $)$ with a viability $>92 \%$ were incubated with $9.5 \times 10^{-6}, 1.9 \times 10^{-5}, 2.8 \times 10^{-5}, 3.8 \times 10^{-5}$ and 5.7 $\times 10^{-5} \mathrm{M}$ Jade; $2.8 \times 10^{-4}, 5.7 \times 10^{-4}, 8.3 \times 10^{-4}, 1.1 \times$ $10^{-3}$ and $1.7 \times 10^{-3} \mathrm{M}$ Gaucho; $0.6 \times 10^{-1}, 0.9 \times 10^{-1}, 1.2$ $\times 10^{-1}, 1.3 \times 10^{-1}$ and $1.4 \times 10^{-1} \mathrm{M}$ Calypso; $1.2 \times 10^{-1}$, $2.4 \times 10^{-1}, 4.8 \times 10^{-1}, 7.1 \times 10^{-1}$ and $9.5 \times 10^{-1} \mathrm{M}$ Poncho in $1 \mathrm{~mL}$ of $1640 \mathrm{RPMI}$ medium at $37^{\circ} \mathrm{C}$ for $2 \mathrm{~h}$. The controls consisted of human peripheral lymphocytes $\left(5 \times 10^{5}\right.$ cells $)$ in RPMI 1640 medium under the same conditions. After treatments, the cells were washed twice with RPMI 1640 medium and subjected immediately to the cell viability and alkaline comet assays.

2.6. Alkaline Comet Assay. The alkaline comet assay was performed according to procedures previously described by $[50,51]$. Briefly, lymphocytes (2,500 cells) were mixed with $90 \mu \mathrm{L}$ of low-melting-point agarose $(0.5 \%)$ at $37^{\circ} \mathrm{C}$, placed on fully frosted slides (Fisher) coated with a thin layer of normal-melting-point agarose (1\%) and covered with a coverslip. Two slides were made for each treatment. The slides were kept at $4^{\circ} \mathrm{C}$ for $5 \mathrm{~min}$ to allow the agarose to solidify. The coverslip was then carefully removed, and the slides were immersed in a Coplin staining jar containing a freshly prepared cold lysis solution $(2.5 \mathrm{M} \mathrm{NaCl}, 100 \mathrm{mM}$ EDTA, $10 \mathrm{mM}$ Tris, $1 \%$ Triton X-100, and 10\% DMSO, $\mathrm{pH}=10)$ at $4^{\circ} \mathrm{C}$ for $1 \mathrm{~h}$. The slides were placed in a horizontal electrophoresis chamber (Owl A5, Lab System Inc) containing freshly prepared cold electrophoresis alkaline buffer $(300 \mathrm{mM} \mathrm{NaOH}, 1 \mathrm{mM}$ EDTA, $\mathrm{pH}=13)$ for $20 \mathrm{~min}$ to unwind the DNA. Electrophoresis was carried out at $25 \mathrm{~V}$ and $300 \mathrm{~mA}$ for $20 \mathrm{~min}$ in darkness to prevent additional DNA damage. The slides were then washed three times with freshly prepared neutralization buffer $(0.4 \mathrm{M}$ Tris, $\mathrm{pH}$ 7.5) for $5 \mathrm{~min}$, fixed with cold absolute methanol for $5 \mathrm{~min}$, and air-dried at room temperature. Next, $50 \mu \mathrm{L}$ of ethidium bromide $(20 \mathrm{mg} / \mathrm{mL})$ was added to each slide to stain the DNA. The slides were labeled with a code that was unfamiliar to the viewer and examined with an Axiostar Plus Carl Zeiss fluorescent microscope equipped with an excitation filter $(515-560 \mathrm{~nm})$ and a barrier filter $(590 \mathrm{~nm})$. To visualize DNA damage, slides were observed at 40x magnification 


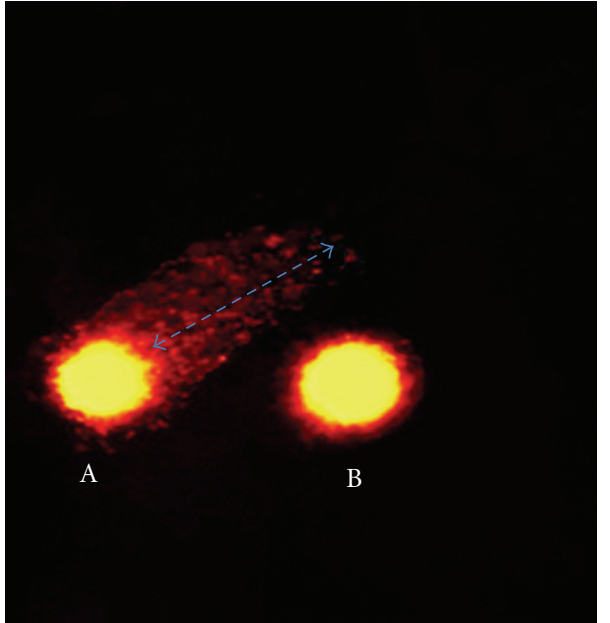

Figure 2: Human peripheral blood lymphocytes. A: nuclei with DNA damage (with comet) and B: nuclei without DNA damage (without comet).

using a micrometric eyepiece/objective combination (1 unit $=2.41 \mu \mathrm{m}$ at $40 \mathrm{x}$ magnification). Two parameters were used to determine genotoxicity: (a) comet frequency (nuclei with DNA damage) in 50 randomly selected nuclei on each slide (two slides per treatment); and (b) comet tail length (DNA fragmentation), evaluated by measuring the distance (in $\mu \mathrm{m})$ from the nuclear region to the end of the tail in 100 consecutive nuclei (Figure 2A).

2.7. Statistical Analysis. Comet frequency, tail length, and cell viability are reported as the mean \pm standard error of the mean (SEM) obtained from three independent experiments for each treatment. An analysis of variance (ANOVA) and the Newman-Keuls test were used to determine significant differences between the treatment groups. Significance was defined as $P<0.001$. The relationship between comet frequency and comet tail length was evaluated using linear regression analysis.

\section{Results}

3.1. In Vitro Genotoxicity of Neonicotinoid Insecticides in Human Peripheral Blood Lymphocytes. Exposure to all concentrations of Calypso 480 SC (thiacloprid), Poncho (Clothianidin), and Gaucho and Jade (two imidacloprid commercial formulations) for $2 \mathrm{~h}$ caused significant increases in the two measures of genotoxicity, percentage of comets and the tail length, in relation to the controls $(P<0.001$; Figures 3 and 4). In cells exposed to $0.6 \times 10^{-1}, 0.9 \times 10^{-1}, 1.2 \times 10^{-1}$, $1.3 \times 10^{-1}$, and $1.4 \times 10^{-1} \mathrm{M}$ Calypso, the mean comet frequency ranged from $20 \pm 0.6$ to $79 \pm 0.7$ and the tail length ranged from $17.9 \pm 0.1$ to $50.3 \pm 1.0 \mu \mathrm{m}$. In cells exposed to $1.2 \times 10^{-1}, 2.4 \times 10^{-1}, 4.8 \times 10^{-1}, 7.1 \times 10^{-1}$, and $9.5 \times 10^{-1} \mathrm{M}$ Poncho, the mean comet frequency ranged from $7 \pm 0.2$ to $82 \pm 3.4$ and the tail length ranged from $14.2 \pm 0.8$ to $63.3 \pm 2.0 \mu \mathrm{m}$. In cells exposed $9.5 \times 10^{-6}$, $1.9 \times 10^{-5}, 2.8 \times 10^{-5}, 3.8 \times 10^{-5}$ and $5.7 \times 10^{-5} \mathrm{M}$ Jade, the mean comet frequency ranged from $28 \pm 2.0$ to $92 \pm 1.7$ and the tail length ranged from $5.5 \pm 1.1$ to $35.6 \pm 2.2 \mu \mathrm{m}$. In cells exposed to $2.8 \times 10^{-4}, 5.7 \times 10^{-4}, 8.3 \times 10^{-4}, 1.1 \times$ $10^{-3}$ and $1.7 \times 10^{-3} \mathrm{M}$ Gaucho, the mean comet frequency ranged from $22 \pm 1.2$ to $90 \pm 2.8$ and the tail length ranged from $15.71 \pm 1.2$ to $33.94 \pm 1.9 \mu \mathrm{m}$ (Figures 3 and 4 ). At the highest concentrations, all neonicotinoid insecticides caused severe DNA damage in $80-90 \%$ of nuclei, exhibiting a higher comet frequency and greater tail length when compared to controls (Figures 3 and 4).

The relative genotoxicities of neonicotinoid insecticides in human peripheral blood lymphocytes in vitro are as follows: Jade $>$ Gaucho $>$ Calypso $>$ Poncho (Figures 3 and 4). Control lymphocytes from three healthy volunteer donors showed low basal DNA damage (Figures 3 and 4).

The linear regression analysis of the mean comet frequency and the comet tail length in all neonicotinoid insecticides showed positive correlations $(r=0.9)$, indicating a concentration-dependent relationship (Figures 5 and 6).

3.2. In Vitro Cytotoxicity of Neonicotinoid Insecticides in Human Peripheral Blood Lymphocytes. In the preliminary experiments, human peripheral blood lymphocytes were exposed to different concentrations of four neonicotinoid insecticides for $2 \mathrm{~h}$. After treatment, cell viability was evaluated by trypan blue dye-exclusion staining. The data indicate that concentrations of $9.5 \times 10^{-6}, 1.9 \times 10^{-5}, 2.8 \times 10^{-5}$, $3.8 \times 10^{-5}$, and $5.7 \times 10^{-5} \mathrm{M}$ Jade; $2.8 \times 10^{-4}, 5.7 \times 10^{-4}$, $8.3 \times 10^{-4}, 1.1 \times 10^{-3}$ and $1.7 \times 10^{-3} \mathrm{M}$ Gaucho; $0.6 \times$ $10^{-1}, 0.9 \times 10^{-1}, 1.2 \times 10^{-1}, 1.3 \times 10^{-1}$ and $1.4 \times 10^{-1} \mathrm{M}$ Calypso; and $1.2 \times 10^{-1}, 2.4 \times 10^{-1}, 4.8 \times 10^{-1}, 7.1 \times$ $10^{-1}$ and $9.5 \times 10^{-1} \mathrm{M}$ Poncho did not produce statistically significant differences in cell viability when compared to controls $(P<0.001$; Figure 7$)$. These concentrations were then used for the alkaline comet assay. However, when the human lymphocytes were exposed to $18 \times 10^{-3} \mathrm{M}$ Jade, $2.0 \times$ $10^{-3} \mathrm{M}$ Gaucho, $2.0 \times 10^{-1} \mathrm{M}$ Calypso, and 1.07 M Poncho, cell viability was significantly decreased in relation to the control values $(P<0.001)$. Cell death occurred following exposure to $30 \times 10^{-3} \mathrm{M}$ Jade, $3.3 \times 10^{-3} \mathrm{M}$ Gaucho, $2.8 \times$ $10^{-1} \mathrm{M}$ Calypso, and $1.42 \mathrm{M}$ Poncho (Figure 7).

\section{Discussion}

Neonicotinoid pesticides represent $17 \%$ of all processed insecticides on the global market [54]. This is largely because they are less persistent in the environment, do not accumulate in animal tissues, and are less toxic to mammals than older classes of insecticides. Neonicotinoids, therefore, represent a new and "less hazardous" class of agrochemicals $[2,55,56]$. However, until now, no studies have been performed to evaluate their genotoxic and cytotoxic effects. The present study evaluated the genotoxic and cytotoxic effects of the neonicotinoid insecticides Calypso, Poncho, Gaucho, and Jade in human peripheral blood lymphocytes in vitro using the alkaline comet and trypan blue exclusion assays. The alkaline comet assay is an early biomarker that is widely used to detect DNA damage induced by environmental 


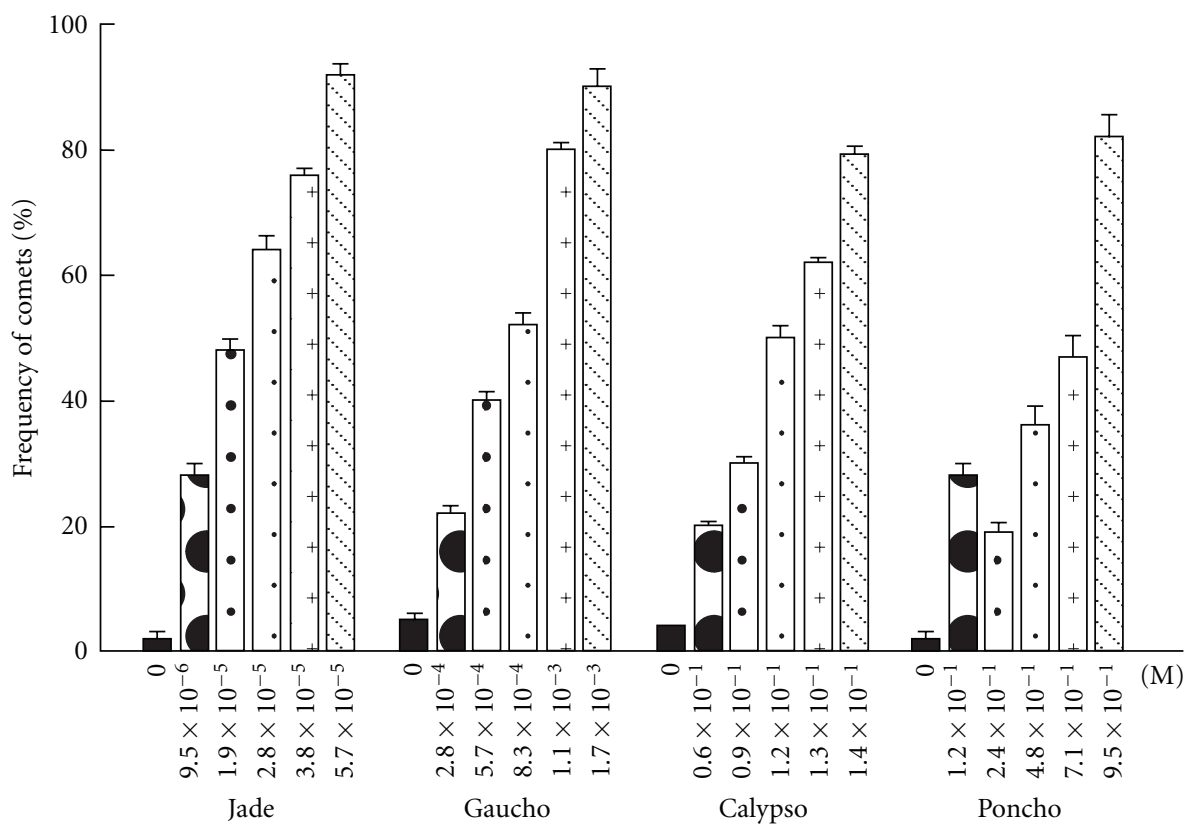

FIGURE 3: Mean frequency of nuclei with comet in human peripheral blood lymphocytes exposed in vitro to neonicotinoid insecticides. The bars represent the mean values \pm SEM of the comet from the three independent experiments.

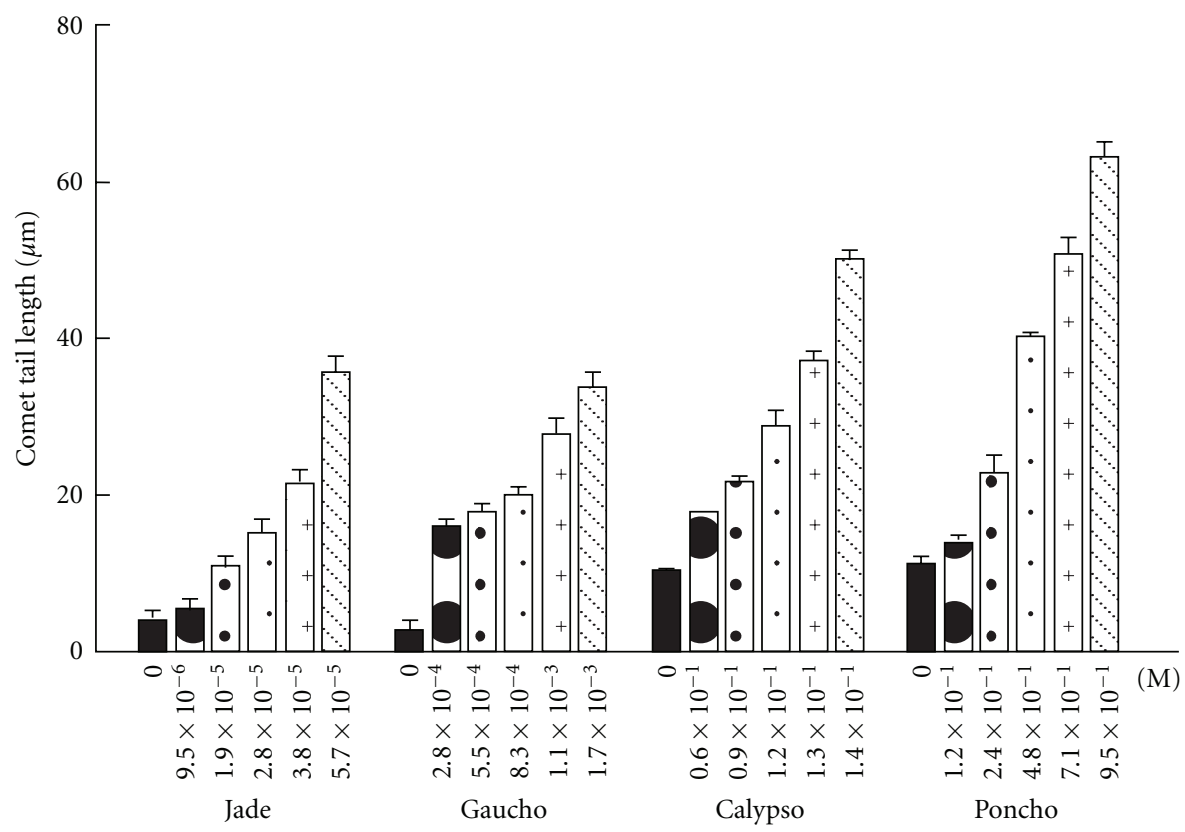

FIGURE 4: Mean comet tail length in human peripheral blood lymphocytes exposed in vitro to neonicotinoid insecticides. The bars represent the mean values \pm SEM of the comet tail length from the three independent experiments.

chemical agents, such as pesticides. When compared with other cytogenetic tests, such as sister chromatid exchange, micronuclei formation, and chromosomal aberration assays, the comet assay is the most rapid and sensitive method to evaluate the genotoxic agents both in vitro and in vivo; this assay does not require proliferation of cells, is applicable to all eukaryotic cells, and can obtain reproducible results in a very short amount of time [51].
Low concentrations of all the tested neonicotinoid pesticides induced DNA damage, resulting in significant increases in the two measures of genotoxicity used in the present study: comet frequency and tail length. Our results are in agreement with data obtained from in vitro genotoxic studies performed with the insecticide imidacloprid. Exposure to $1 \mathrm{mM}$ Admire that was metabolically activated in vitro with a rat liver S9 enzymatic mixture produced calf thymus DNA adducts [14]. 


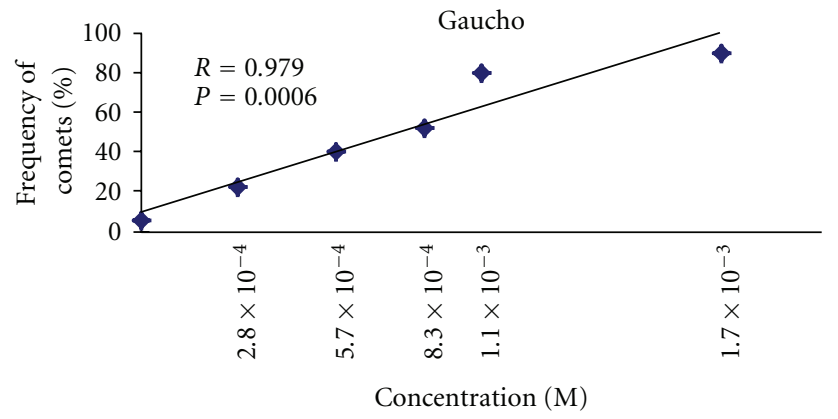

(a)

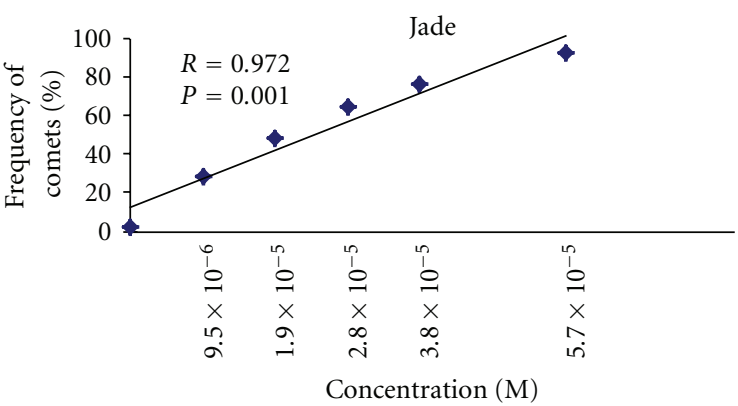

(c)

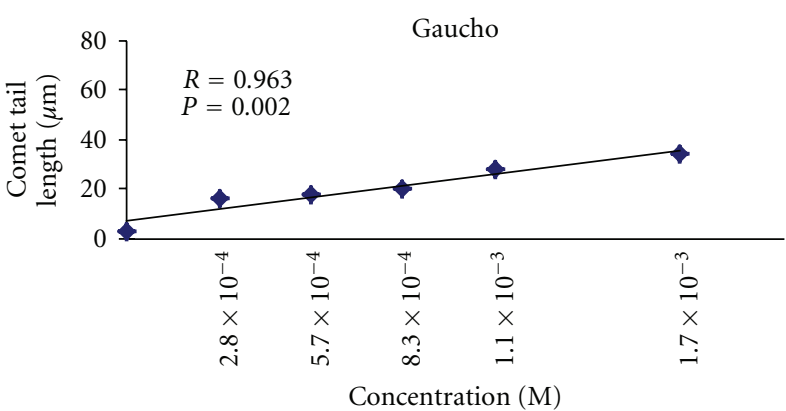

(b)

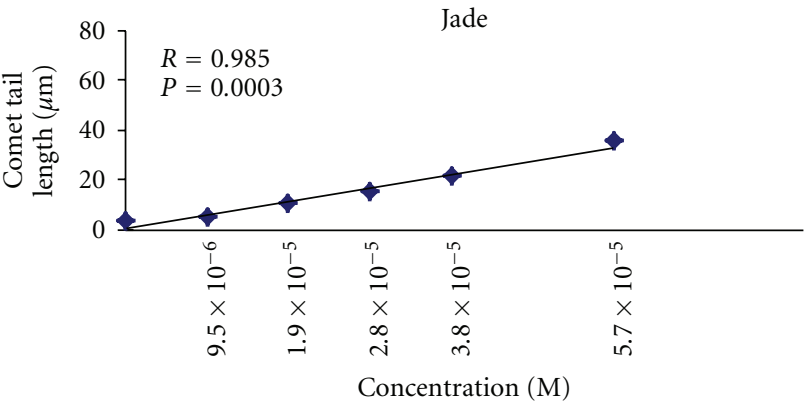

(d)

FIGURE 5: Regression lines of the frequency of comets and comet tail length in human peripheral blood lymphocytes exposed in vitro to Gaucho and Jade.

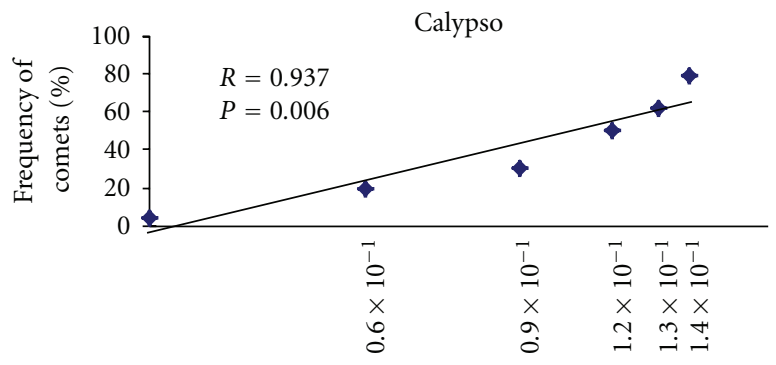

Concentration (M)

(a)

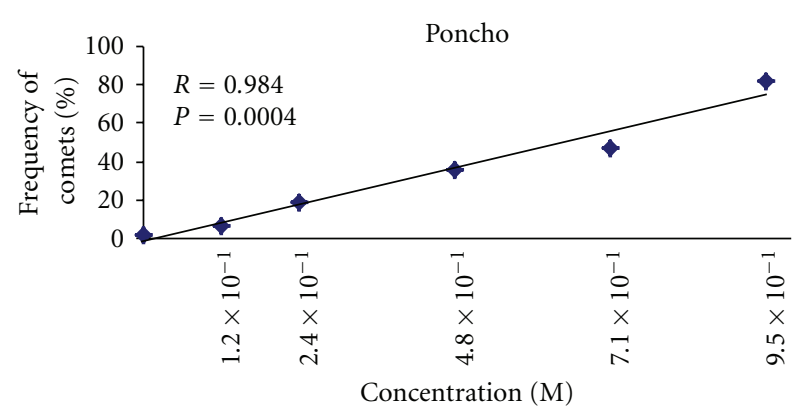

(c)

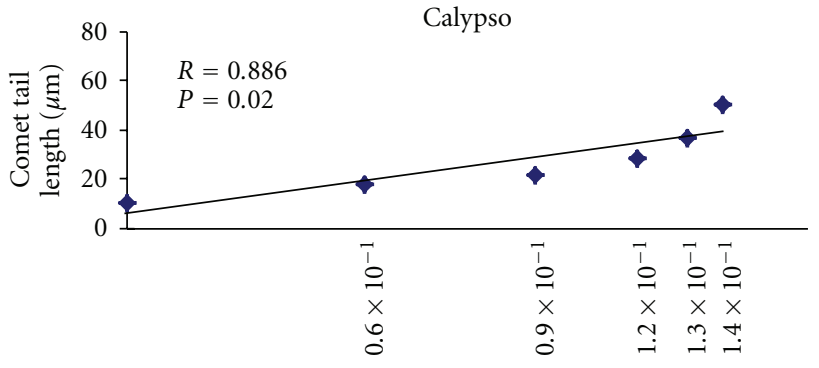

Concentration (M)

(b)

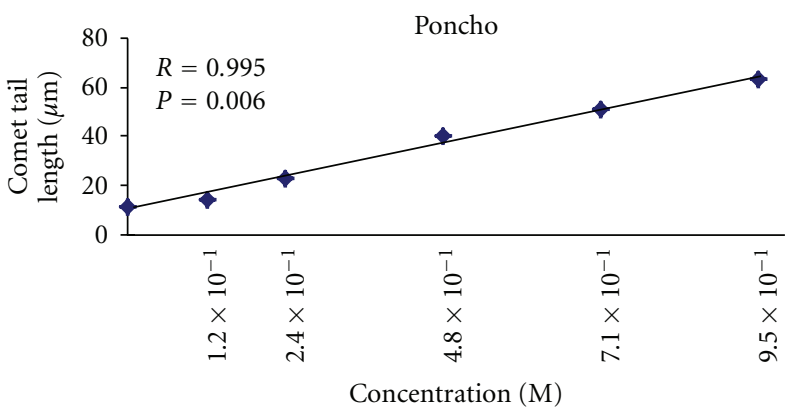

(d)

Figure 6: Regression lines of the frequency of comets and comet tail length in human peripheral blood lymphocytes exposed in vitro to Calypso and Poncho. 


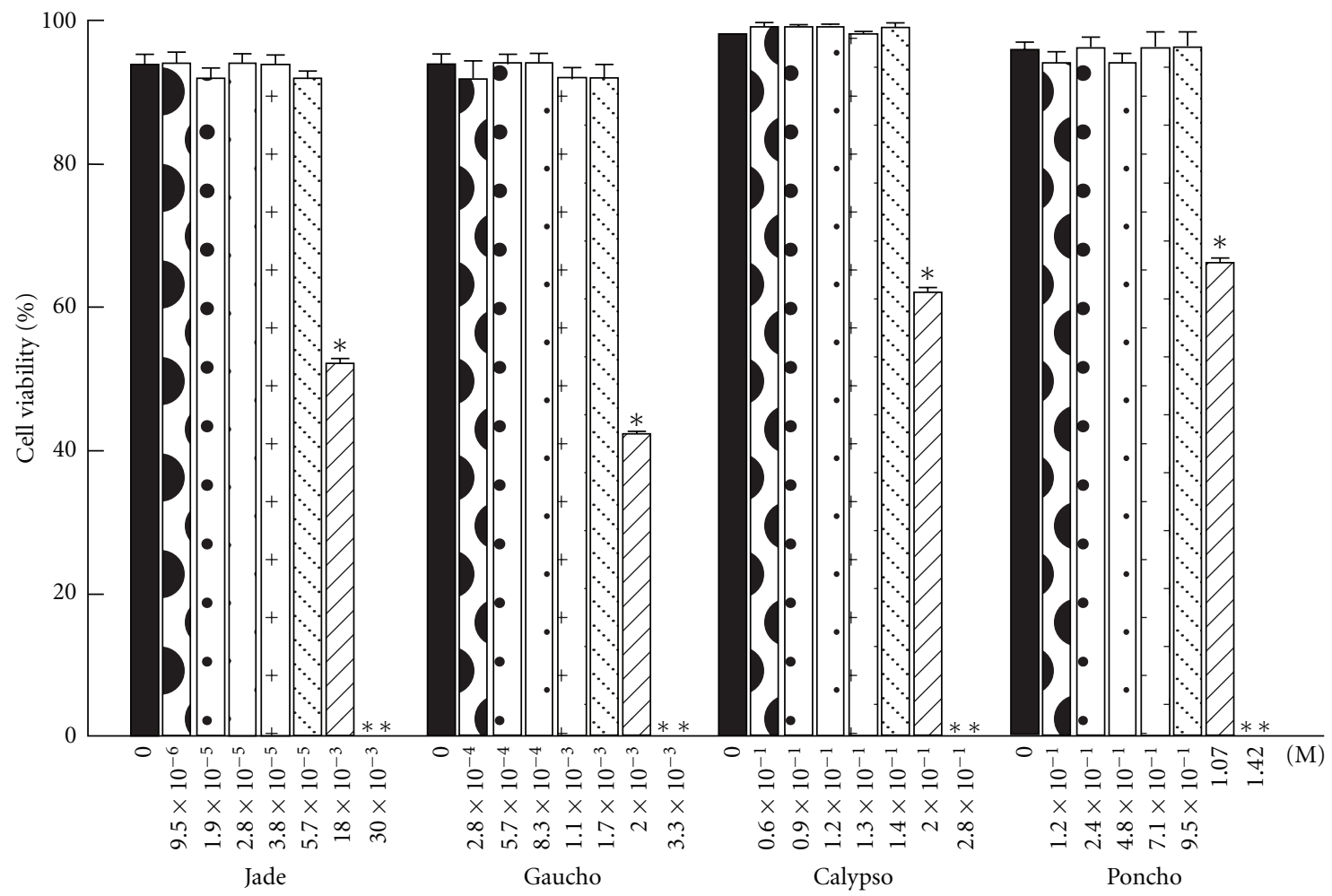

FIgURE 7: Mean viability of the human peripheral blood lymphocytes exposed in vitro to neonicotinoid insecticides. The bars represent the mean values \pm SEM from three independent experiments. ${ }^{*}$ indicates significant decrease in cell viability; ${ }^{* *}$ indicates cell death.

Concentrations of $25-100 \mu \mathrm{L} /$ plaque Confidor significantly augmented the reverse mutation rate of TA 98 and TA 100 Salmonella typhimurium strains, both with and without in vitro S9 metabolic activation (S9 enzymatic mix from rat livers) [16]. In culture, human peripheral blood lymphocytes exposed to 0.1 or $0.5 \mathrm{mg} / \mathrm{L}$ imidacloprid (pure compound) showed significantly increased levels of sister chromatid exchange and micronuclei formation [17], and 0.05, 0.1, 0.2 , and $0.5 \mathrm{mg} / \mathrm{L}$ imidacloprid enhanced DNA strand breaks [17]. However, $0.1,1,5,50$, and $100 \mu \mathrm{g} / \mathrm{mL}$ imidacloprid incubated with the same human cells in vitro were negative for sister chromatid exchange and micronuclei formation [19]. Exposure to $20 \mu \mathrm{M}$ imidacloprid (pure compound) and its commercial formulation, Confidor 200 SL, significantly increased DNA strand breaks in leukocytes and micronucleus frequency in peripheral blood lymphocytes, both with and without in vitro S9 metabolic activation [18]. Recently, a significant increase in the levels of sister chromatid exchange, micronuclei formation, and chromosomal aberrations was observed in human lymphocytes incubated with $25,30,35$, or $40 \mu \mathrm{g} / \mathrm{mL}$ of the commercial acetamiprid formulation, Mosetam 20 SP for 24 or $48 \mathrm{~h}$ [22]. In laboratory animals, the imidacloprid commercial formulation Confidor and pure imidacloprid compound were positive for micronuclei formation and chromosomal aberrations in Wistar albino rat bone-marrow cells treated with 50 or $100 \mathrm{mg} / \mathrm{kg}$ body weight for 90 days [16]. Exposure to $300 \mathrm{mg} / \mathrm{kg}$ body weight imidacloprid (Confidor) for $24 \mathrm{~h}$ significantly increased micronuclei frequency of in rat bone-marrow cells [19].
Eisenia fetida exposed to 0.2 or $0.5 \mathrm{mg} / \mathrm{kg}$ imidacloprid in dry soil for 14 days exhibited spermatic malformations. The same species showed a significant dose-dependent increase in DNA damage in coelomocytes exposed to $0.05,0.1,0.2$, or $0.5 \mathrm{mg} / \mathrm{L}$ imidacloprid for $2 \mathrm{~h}$ [15]. Rana $\mathrm{N}$-Hallowell exposed to $0.05,0.1,0.2,0.5,8$, or $32 \mathrm{mg} / \mathrm{L}^{-1}$ imidacloprid (pure compound) for 7 days exhibited a significant increase in the percentage of peripheral erythrocytes with micronuclei and DNA break strands [20].

The molecular mechanisms driving neonicotinoid insecticide genotoxicity are largely unknown. Recent in vitro studies have indicated that acetamiprid may induce reactive oxygen species (ROS) generation in bacteria [57]. However, Yurkat cells and lymphocytes incubated with imidacloprid did not show increased ROS production [18]. Although these results are inconsistent, we suggest that neonicotinoid insecticides, such as Calypso, Poncho, Gaucho, and Jade, are direct genotoxic agents that could act a source of free radicals or ROS in exposed human cells. ROS, such as superoxide anions $\left(\mathrm{O}_{2}{ }^{\bullet}\right)$, hydrogen peroxide $\left(\mathrm{H}_{2} \mathrm{O}_{2}\right)$, and hydroxyl radicals $\left(\mathrm{OH}^{-}\right)$, are highly reactive with DNA and produce damage, including single- and double-strand DNA breaks and nucleoside modifications. The DNA damage or DNA strand breaks as detected in this study could be considered a kind of lesion potentially premutagenic [58].

Considering that human exposure to pesticides could produce an accumulation of DNA lesions and if the DNA is not repaired could be an initial event in the process of chemical carcionogenesis $[47,48]$, and the development of 
tumors may eventually occur [49]. In general, the induction of genotoxicity such as chromosomal and DNA lesions may lead to futher problem of mutagenic and carcinogenic activity $[49,58]$. DNA damage is the under cause of mutations leading to cancer [58]. This is in-line with previous epidemiological studies that demonstrated a relationship between pesticides exposure and the occurrence of cancer [49].

In this study, we demonstrated that four commercial neonicotinoid formulations, Jade, Gaucho and Calypso (N-nitroguanidine derivatives), and Poncho (a N-cyanoaminide derivate), directly induce DNA damage in a concentration-dependent manner but independently of their chemical structure. We observed comet formation and production of DNA breaks following exposure to each insecticide. When comparing the genotoxic action of all the tested insecticides, we observed that Jade (granulated imidacloprid) was more genotoxic than Gaucho (emulsion imidacloprid) in human cells in vitro. Calypso (thiacloprid) was more genotoxic than Poncho (clothianidin). The chemical composition (e.g., solvents, emulsifiers, dispersion agents, and other additives) of each formulation and the concentration of the active ingredient (i.e., thiacloprid, clothianidin, and imidacloprid) determined the genotoxicity in the human peripheral blood lymphocytes in vitro. Genotoxicity was reflected in the differential production of the DNA damage and its effects on cellular viability. Although there were no observed cytotoxic effects following exposure to the neonicotinoid insecticide concentrations used to detect genotoxicity, we did observe that, at high concentrations, all pesticides significantly reduced human lymphocyte viability to $18 \times 10^{-3} \mathrm{M}$ Jade, $2.0 \times 10^{-3} \mathrm{M}$ Gaucho, $2.0 \times 10^{-1} \mathrm{M}$ Calypso, and 1.07 M Poncho. Particularly, we observed that to concentrations of $2.0 \times 10^{-1} \mathrm{M}$ Calypso and $1.07 \mathrm{M}$ Poncho produced more than $50 \%$ killing of the cells and higher DNA fragmentation which was also reflected by presence apoptotic nuclei or comets without nuclei ("clouds") and presence of residues of insecticides. Possibly, the chemical formulations of Poncho and Calypso play an important role in tolerance of human peripheral lymphocytes exposed of short time to maximum concentrations for the pesticides. Perhaps, insecticides increased intracellular level of ROS or free radicals in human cells that trigger various damaging process such as apoptosis, the decrease ATP level, inhibiting of intracellular proteins activities and others, and finally metabolic poising with death cell to $30 \times 10^{-3} \mathrm{M}$ Jade, $3.3 \times$ $10^{-3} \mathrm{M}$ Gaucho, $2.8 \times 10^{-1} \mathrm{M}$ Calypso, and $1.42 \mathrm{M}$ Poncho [59]. Unfortunately, the concentrations used in this study may be difficult to translate to a chronic exposure scenario in humans. Nevertheless, in vitro studies are warranted to elucidate the mechanism of toxicity at low-level exposure. In addition, it has reported that using human lymphocytes for the genotoxicity studies could explain the best result for humans.

Considering the ubiquitous environmental presence of neonicotinoid insecticides, this study provided new information relative to the cytotoxic effects of these agrochemicals. Although further studies investigating the details of cytotoxicity mechanisms are necessary before definitive conclusions can be drawn, our results suggest that these insecticides are risk to organisms. Furthermore, increased DNA damage in human lymphocytes indicates potential genetic hazards posed by commonly used pesticides and emphasizes the need and the importance of protective measures and safety regulations to minimize to exposure.

On the other hand, some studies have documented the presence of residues or metabolic intermediates of imidacloprid (Confidor 200SL), thiacloprid, and clothianidin in fruits, vegetables, soil, and water [60-62]. Therefore, biotransformation of these neonicotinoid insecticides has been studied in plants [63] and mammalian systems [54]. The metabolic pathways of neonicotinoids such as imidacloprid, nitenpyram, thiacloprid, acetamiprid, and dinotefuran have studied in mice [63] and spinach [54]. The major primary metabolic reactions (Phase I metabolism) are hydroxylation, desaturation, dealkylation, sulfoxidation, nitroreduction, catalyzed by microsomal CYP-450 isoenzymes [54, $63,64]$. Cytosolic aldehyde oxidase is a nitroreductase for some neonicotinoids. Phase II metabolism involves methylation, acetylation, and formation of glucoronide, glucoside, amino acid, and sulfate- and glutathione-derived conjugates. Metabolites in some cases contribute to mammalian hepatotoxicity and carcinogenesis [64].

In previous studies, we demonstrated that the in vivo vegetal metabolic activation (S10 enzymatic from Vicia faba root) of pesticides, such as carbamates, induced significant increases in the frequency of sister chromatid exchange [65-67], DNA strand breaks, and alterations in the cellular proliferation kinetics of the human peripheral lymphocytes [52]. Original compounds and metabolites may pass through the animal digestive tract and can be activated. When the animal and plant are used as food, these compounds could represent a risk to health [68]. On the other hand, when the agrochemical get into food plant, these substances can be objects of further transformations, remain in an unaltered state, or are reactive by human or animal digestive enzymes producing perhaps physiological adverse effects on organisms [68].

The presence DNA damaged at low concentrations of these neonicotinoid insecticides contributes to the toxicology of these environmental because they are applied on food agricultural fields to higher concentrations (Calypso $22-30 \mathrm{~mL} / 100 \mathrm{~L}$ water; Poncho $100 \mathrm{~mL} / 100 \mathrm{~L}$ water, Jade $20 \mathrm{Kg} / \mathrm{ha}$, and Gaucho $160 \mathrm{~g} / \mathrm{Kg}$ seeds) [1] than concentrations assayed in this study and carry up to atmosphere, air, and aquatic systems, and they represent routes of introduction to organisms and are a risk factor on human and animal health.

\section{Summary}

In summary, our study is the first to show the genotoxic and cytotoxic actions of the neonicotinoid insecticides Calypso, Poncho, Jade, and Gaucho in human peripheral blood lymphocytes in vitro. At high concentrations, all pesticides significantly reduced human lymphocyte viability and caused cell death. By comparing the genotoxic and 
cytotoxic effects of the pesticides, we observed that Jade caused more genotoxicity and cytotoxicity than Gaucho and Calypso and Poncho. These results corroborated that the alkaline comet assay is an excellent and sensitive test to evaluate DNA damage induced by pesticides in human peripheral blood lymphocytes in vitro. However, more genotoxic studies with different biological test systems are necessary to confirm that these insecticides are dangerous to animals, including humans, and to clarify the genotoxic and cytotoxic mechanism of neonicotinoid insecticides.

\section{Conflict of Interests}

Authors declare that there are not conflicts of interest.

\section{Acknowledgments}

This study was financially supported by the Programa Apoyo Proyectos de Investigación e Innovación Tecnológica, Dirección General Apoyo al Personal Académico [IN213908], of the Universidad Nacional Autónoma de México. The authors are grateful to the chemist Ana Luisa Alarcón-Jiménez of Laboratorio de Contaminación Ambiental del Centro de Ciencias de la Atmósfera and Carlos Orozco-Castellanos for their technical assistance in the alkaline comet assay.

\section{References}

[1] Bayer CropScience México, 2008, http://www.bayercropscience.com.mx/.

[2] S. D. Bolboaca and L. Jäntschi, "Molecular descriptors family on structure activity relationships. 2. Insecticidal activity of neonicotinoid compounds," Journal of Pesticide Science, vol. 4, pp. 78-85, 2005.

[3] R. Nauen and I. Denholm, "Resistance of insect pests to neonicotinoid insecticides: current status and future prospects," Archives of Insect Biochemistry and Physiology, vol. 58, no. 4, pp. 200-215, 2005.

[4] M. Tomizawa and J. E. Casida, "Neonicotinoid insecticide toxicology: mechanisms of selective action," Annual Review of Pharmacology and Toxicology, vol. 45, pp. 247-268, 2005.

[5] M. Ihara, M. Shimomura, C. Ishida et al., "A hypothesis to account for the selective and diverse actions of neonicotinoid insecticides at their molecular targets, nicotinic acetylcholine receptors: catch and release in hydrogen bond networks," Invertebrate Neuroscience, vol. 7, no. 1, pp. 47-51, 2007.

[6] N. S. Millar and I. Denholm, "Nicotinic acetylcholine receptors: targets for commercially important insecticides," Invertebrate Neuroscience, vol. 7, no. 1, pp. 53-66, 2007.

[7] Environmental Protection Agency, "Thiacloprid; pesticide tolerance," Federal Register, vol. 68, pp. 66561-66571, 2002.

[8] Environmental Protection Agency, "Clothianidin; pesticide tolerance,” Federal Register, vol. 68, pp. 32390-32400, 2003.

[9] World Health Organization, The WHP Recommended Classification of Pesticides by Hazard and Guidelines to Classification, World Health Organization Programme on Chemical Safety, Geneva, Switzerland, 2009.

[10] F. M. Fishel, "Pesticide toxicity profile: neonicotionoid pesticides," 2010, http://edis.ifas.ufl.edu/.
[11] T. Green, A. Toghill, R. Lee, F. Waechter, E. Webe, and J. Noakes, "Thiamethoxam induced mouse liver tumors and their relevance to humans-part 1: mode of action studies in the mouse," Toxicological Sciences, vol. 8, pp. 36-47, 2005.

[12] T. Green, A. Toghill, R. Lee et al., "Thiamethoxam induced mouse liver tumors and their relevance to humans-part 2: species differences in response," Toxicological Sciences, vol. 86, no. 1, pp. 48-55, 2005.

[13] J. L. Gomez-Eyles, C. Svendsen, L. Lister, H. Martin, M. E. Hodson, and D. J. Spurgeon, "Measuring and modelling mixture toxicity of imidacloprid and thiacloprid on Caenorhabditis elegans and Eisenia fetida," Ecotoxicology and Environmental Safety, vol. 72, no. 1, pp. 71-79, 2009.

[14] R. G. Shah, J. Lagueux, S. Kapur et al., "Determination of genotoxicity of the metabolites of the pesticides Guthion, Sencor, Lorox, Reglone, Daconil and Admire by 32P-postlabeling," Molecular and Cellular Biochemistry, vol. 169, no. 1-2, pp. 177184, 1997.

[15] Y. Zang, Y. Zhong, Y. Luo, and Z. M. Kong, "Genotoxicity of two novel pesticides for the earthworm, Eisenia fetida," Environmental Pollution, vol. 108, no. 2, pp. 271-278, 2000.

[16] N. U. Karabay and M. G. Oguz, "Cytogenetic and genotoxic effects of the insecticides, imidacloprid and methamidophos," Genetics and Molecular Research, vol. 4, no. 4, pp. 653-662, 2005.

[17] S. Feng, Z. Kong, X. Wang, P. Peng, and E. Y. Zeng, "Assessing the genotoxicity of imidacloprid and RH-5849 in human peripheral blood lymphocytes in vitro with comet assay and cytogenetic tests," Ecotoxicology and Environmental Safety, vol. 61, no. 2, pp. 239-246, 2005.

[18] C. Costa, V. Silvari, A. Melchinib et al., "Genotoxicity of imidacloprid in relation to metabolic activation and composition of the commercial product," Mutation Research-Genetic Toxicology and Environmental Mutagenesis, vol. 672, pp. 40-44, 2009.

[19] G. Demsia, D. Vlastos, M. Goumenou, and D. P. Matthopoulos, "Assessment of the genotoxicity of imidacloprid and metalaxyl in cultured human lymphocytes and rat bonemarrow," Mutation Research-Genetic Toxicology and Environmental Mutagenesis, vol. 634, no. 1-2, pp. 32-39, 2007.

[20] S. Feng, Z. Kong, X. Wang, L. Zhao, and P. Peng, "Acute toxicity and genotoxicity of two novel pesticides on amphibian, Rana N. Hallowell," Chemosphere, vol. 56, no. 5, pp. 457-463, 2004.

[21] A. Lin, Y. Zhu, and Y. Tong, "Evaluation of genotoxicity of combined soil pollution by cadmium and imidacloprid," Science in China C, vol. 48, no. 1, pp. 7-13, 2005.

[22] A. Y. Kocaman and M. Topaktaş, "In vitro evaluation of the genotoxicity of acetamiprid in human peripheral blood lymphocytes," Environmental and Molecular Mutagenesis, vol. 48, no. 6, pp. 483-490, 2007.

[23] I. W. Wu, J. L. Lin, and E. T. Cheng, "Acute poisoning with the neonicotinoid insecticide imidacloprid in N-methyl pyrrolidone," Journal of Clinical Toxicology, vol. 39, no. 6, pp. 617-621, 2001.

[24] P. Proença, H. Teixeira, F. Castanheira et al., "Two fatal intoxication cases with imidacloprid: LC/MS analysis," Forensic Science International, vol. 153, no. 1, pp. 75-80, 2005.

[25] D. David, I. A. George, and J. V. Peter, "Toxicology of the newer neonicotinoid insecticides imidacloprid poisoning in a human," Journal of Clinical Toxicology, vol. 45, no. 5, pp. 485486, 2007.

[26] F. Mohamed, I. Gawarammana, T. A. Robertson et al., "Acute human self-poisoning with imidacloprid compound: 
a neonicotinoid insecticide," PLOS ONE, vol. 4, no. 4, article e5127, 2009.

[27] T. Imamura, Y. Yanagawa, K. Nishikawa, N. Matsumoto, and T. Sakamoto, "Two cases of acute poisoning with acetamiprid in humans," Journal of Clinical Toxicology, vol. 48, no. 8, pp. 851-853, 2010.

[28] C. Bolognesi, "Genotoxicity of pesticides: review of human biomonitoring studies," Mutation Research-Genetic Toxicology and Environmental Mutagenesis, vol. 543, pp. 251-271, 2003.

[29] G. Van Maele-Fabry, S. Duhayon, and D. Lison, "A systematic review of myeloid leukemias and occupational pesticide exposure," Cancer Causes and Control, vol. 18, no. 5, pp. 457478, 2007.

[30] S. Bull, K. Fletcher, A. R. Boobis, and J. M. Battershill, "Evidence for genotoxicity of pesticides in pesticide applicators: a review," Mutagenesis, vol. 21, no. 2, pp. 93-103, 2006.

[31] D. S. Rupa, P. P. Reddy, K. Sreemannarayana, and O. S. Reddi, "Frequency of sister chromatid exchange in peripheral lymphocytes of male pesticide applicators," Environmental and Molecular Mutagenesis, vol. 18, no. 2, pp. 136-138, 1991.

[32] S. Gómez-Arroyo, Y. Díaz-Sánchez, M. A. Meneses-Pérez, R. Villalobos-Pietrini, and J. De León-Rodríguez, "Cytogenetic biomonitoring in a Mexican floriculture worker group exposed to pesticides," Mutation Research-Genetic Toxicology and Environmental Mutagenesis, vol. 466, no. 1, pp. 117-124, 2000.

[33] C. Martínez-Valenzuela, S. Gómez-Arroyo, R. VillalobosPietrini et al., "Genotoxic biomonitoring of agricultural workers exposed to pesticides in the north of Sinaloa State, Mexico," Environment International, vol. 35, no. 8, pp. 11551159, 2009.

[34] D. S. Rupa, P. Rita, P. P. Reddy, and O. S. Reddi, "Screening of chromosomal aberrations and sister chromatid exchanges in peripheral lymphocytes of vegetable garden workers," Human and Experimental Toxicology, vol. 7, no. 4, pp. 333-336, 1988.

[35] E. Carbonell, N. Xamena, A. Creus, and R. Marcos, "Cytogenetic biomonitoring in a Spanish group of agricultural workers exposed to pesticides," Mutagenesis, vol. 8, no. 6, pp. 511-517, 1993.

[36] M. Peluso, F. Merlo, A. Munnia, C. Bolognesi, R. Puntoni, and S. Parodi, "32P-postlabeling detection of DNA adducts in peripheral white blood cells of greenhouse floriculturists from Western Liguria, Italy," Cancer Epidemiology Biomarkers and Prevention, vol. 5, no. 5, pp. 361-369, 1996.

[37] P. Grover, K. Danadevi, M. Mahboob, R. Rozati, B. S. Banu, and M. F. Rahman, "Evaluation of genetic damage in workers employed in pesticide production utilizing the Comet assay," Mutagenesis, vol. 18, no. 2, pp. 201-205, 2003.

[38] F.D. Dick, "Parkinson's diseases and pesticides," British Medical Bulletin, vol. 80, pp. 219-231, 2007.

[39] J. A. Hoppin, D. M. Umbach, S. J. London et al., "Pesticides and atopic and nonatopic asthma among farm women in the agricultural health study," American Journal of Respiratory and Critical Care Medicine, vol. 177, no. 1, pp. 11-18, 2008.

[40] R. M. Sharpe, "How strong is the evidence of a link between environmental chemicals and adverse effects on human reproductive health?" British Medical Journal, vol. 328, no. 7437, pp. 447-451, 2004.

[41] C. Colosio, S. Birindelli, E. Corsini, C. L. Galli, and M. Maroni, "Low level exposure to chemicals and immune system," Toxicology and Applied Pharmacology, vol. 207, no. 2, pp. S320-S328, 2005.

[42] K. P. Cantor, A. Blair, G. Everett et al., "Pesticides and other agricultural risk factors for non-Hodgkin's lymphoma among men in Iowa and Minnesota," Cancer Research, vol. 52, no. 9, pp. 2447-2455, 1992.

[43] M. C. R. Alavanja, M. Dosemeci, C. Samanic et al., "Pesticides and lung cancer risk in the agricultural health study cohort," American Journal of Epidemiology, vol. 160, no. 9, pp. 876-885, 2004.

[44] L. S. Engel, D. A. Hill, J. A. Hoppin et al., "Pesticide use and breast cancer risk among farmers' wives in the agricultural health study," American Journal of Epidemiology, vol. 161, no. 2, pp. 121-135, 2005.

[45] K. L. Bassil, C. Vakill, and M. Sanborn, "Pesticides et cancer," Canadian Family Physician, vol. 53, pp. 1704-1711, 2007.

[46] G. Van Maele-Fabry, S. Duhayon, and D. Lison, "A systematic review of myeloid leukemias and occupational pesticide exposure," Cancer Causes and Control, vol. 18, no. 5, pp. 457478, 2007.

[47] D. W. Fairbairn, P. L. Olive, and K. L. O’Neill, “The comet assay: a comprehensive review," Mutation Research, vol. 339, no. 1, pp. 37-59, 1995.

[48] C. Bernstein, "DNA damage and cancer," SciTopic, 2010, http:/http://www.Scitopic.com/DNA_damage_and_cancer_ .html.

[49] J. Dich, S. H. Zahm, A. Hanberg, and H. O. Adami, "Pesticides and cancer," Cancer Causes and Control, vol. 8, no. 3, pp. 420443, 1997.

[50] N. P. Singh, M. T. McCoy, R. R. Tice, and E. L. Schneider, "A simple technique for quantitation of low levels of DNA damage in individual cells," Experimental Cell Research, vol. 175, no. 1, pp. 184-191, 1988.

[51] R. R. Tice, E. Agurell, D. Anderson et al., "Single cell gel/comet assay: guidelines for in vitro and in vivo genetic toxicology testing," Environmental and Molecular Mutagenesis, vol. 35, no. 3, pp. 206-221, 2000.

[52] M. E. Calderón-Segura, L. López, R. Zúñiga, J. Sánchez, S. Gómez et al., "Metabolic activation of herbicides products by Vicia faba detected in human peripheral lymphocytes using alkaline single cell gel electrophoresis," Toxicology In Vitro, vol. 19, pp. 243-251, 2007.

[53] S. A. Altman, L. Renders, and G. Rao, "Comparison of trypan blue dye exclusion and fluorometric assays for mammalian cell viability determinations," Biotechnology Progress, vol. 9, no. 6, pp. 671-674, 1993.

[54] K. A. Ford and J. E. Casida, "Comparative metabolism and pharmacokinetics of seven neonicotinoid insecticides in spinach," Journal of Agricultural and Food Chemistry, vol. 56, no. 21, pp. 10168-10175, 2008.

[55] A. Elbert, M. Haas, B. Springer, W. Thielert, and R. Nauen, "Applied aspects of neonicotinoid uses in crop protection," Pest Management Science, vol. 64, no. 11, pp. 1099-1105, 2008.

[56] P. Jeschke and R. Nauen, "Neonicotinoids-from zero to hero in insecticide chemistry," Pest Management Science, vol. 64, no. 11, pp. 1084-1098, 2008.

[57] X. H. Yao, H. Min, and Z. M. Lv, "Response of superoxide dismutase, catalase, and ATPase activity in bacteria exposed to acetamiprid," Biomedical and Environmental Sciences, vol. 19, no. 4, pp. 309-314, 2006.

[58] M. Valko, C. J. Rhodes, J. Moncol, M. Izakovic, and M. Mazur, "Free radicals, metals and antioxidants in oxidative stressinduced cancer," Chemico-Biological Interactions, vol. 160, no. 1, pp. 1-40, 2006.

[59] G. P. Das, A. P. Shaik, and K. Jamil, "Estimation of apoptosis and necrosis caused by pesticides in vitro on human lymphocytes using DNA diffusion assay," Drug and Chemical Toxicology, vol. 29, no. 2, pp. 147-156, 2006. 
[60] H. Obana, M. Okihashi, K. Akutsu, Y. Kitagawa, and S. Hori, "Determination of acetamiprid, imidacloprid, and nitenpyram residues in vegetables and fruits by high-performance liquid chromatography with diode-array detection," Journal of Agricultural and Food Chemistry, vol. 50, no. 16, pp. 44644467, 2002.

[61] R. H. Gonzalez, "Pesticide residue decline studies in horticultural export crops," Revista Frutícola, vol. 25, pp. 5-20, 2004.

[62] P. K. Arora, G. Jyot, B. Singh, R. S. Battu, B. Singh, and P. S. Aulakh, "Persistence of imidacloprid on grape leaves, grape berries and soil," Bulletin of Environmental Contamination and Toxicology, vol. 82, no. 2, pp. 239-242, 2009.

[63] K. A. Ford and J. E. Casida, "Chloropyridinyl neonicotinoid insecticides: diverse molecular substituents contribute to facile metabolism in mice," Chemical Research in Toxicology, vol. 19, no. 7, pp. 944-951, 2006.

[64] J. E. Casida, "Neonicotinoid metabolism: compounds, substituents, pathways, enzymes, organisms, and relevance," Journal of Agricultural and Food Chemistry, vol. 59, pp. 29232931, 2011.

[65] S. Gomez-Arroyo, M. E. Calderon-Segura, and R. VillalobosPietrini, "Sister chromatid exchange in human lymphocytes induced by propoxur following plant activation by Vicia faba," Environmental and Molecular Mutagenesis, vol. 26, no. 4, pp. 324-330, 1995.

[66] M. E. Calderón-Segura, S. Gómez-Arroyo, R. VillalobosPietrini, and M. Espinosa-Ramírez, "In vivo and in vitro promutagen activation by Vicia faba of thiocarbamate herbicides molinate and butylate to products inducing sister chromatid exchanges in human lymphocyte cultures," Mutation Research-Genetic Toxicology and Environmental Mutagenesis, vol. 438, no. 2, pp. 81-88, 1999.

[67] S. Flores-Maya, S. Gómez-Arroyo, M. E. Calderón-Segura, R. Villalobos-Pietrini, S. M. Waliszewski, and L. Gómez de la Cruz, "Promutagen activation by Vicia faba of triazine herbicides metribuzin and ametryn through Vicia faba inducing sister chromatid exchanges in human peripheral lymphocyte cultures in vitro and in vivoVicia faba root tip meristem," Toxicology in Vitro, vol. 19, pp. 243-251, 2005.

[68] H. Sandermann, "Plant metabolism of xenobiotics," Trends in Biochemical Sciences, vol. 17, no. 2, pp. 82-84, 1992. 

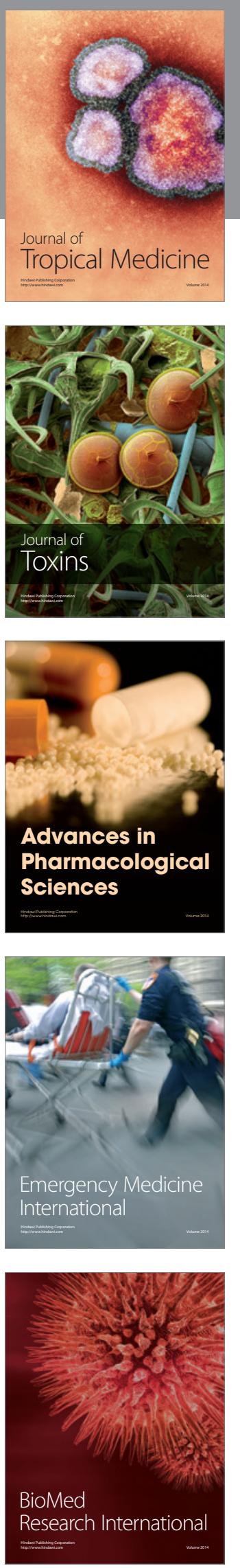
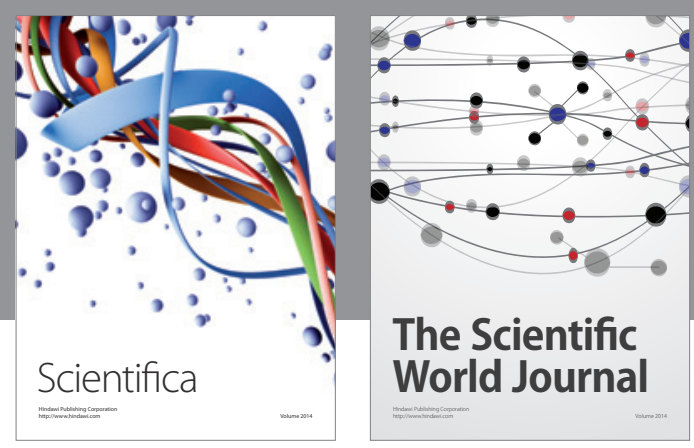

The Scientific World Journal
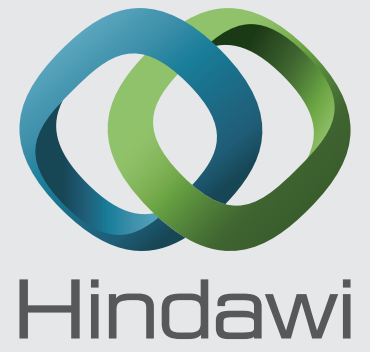

Submit your manuscripts at

http://www.hindawi.com
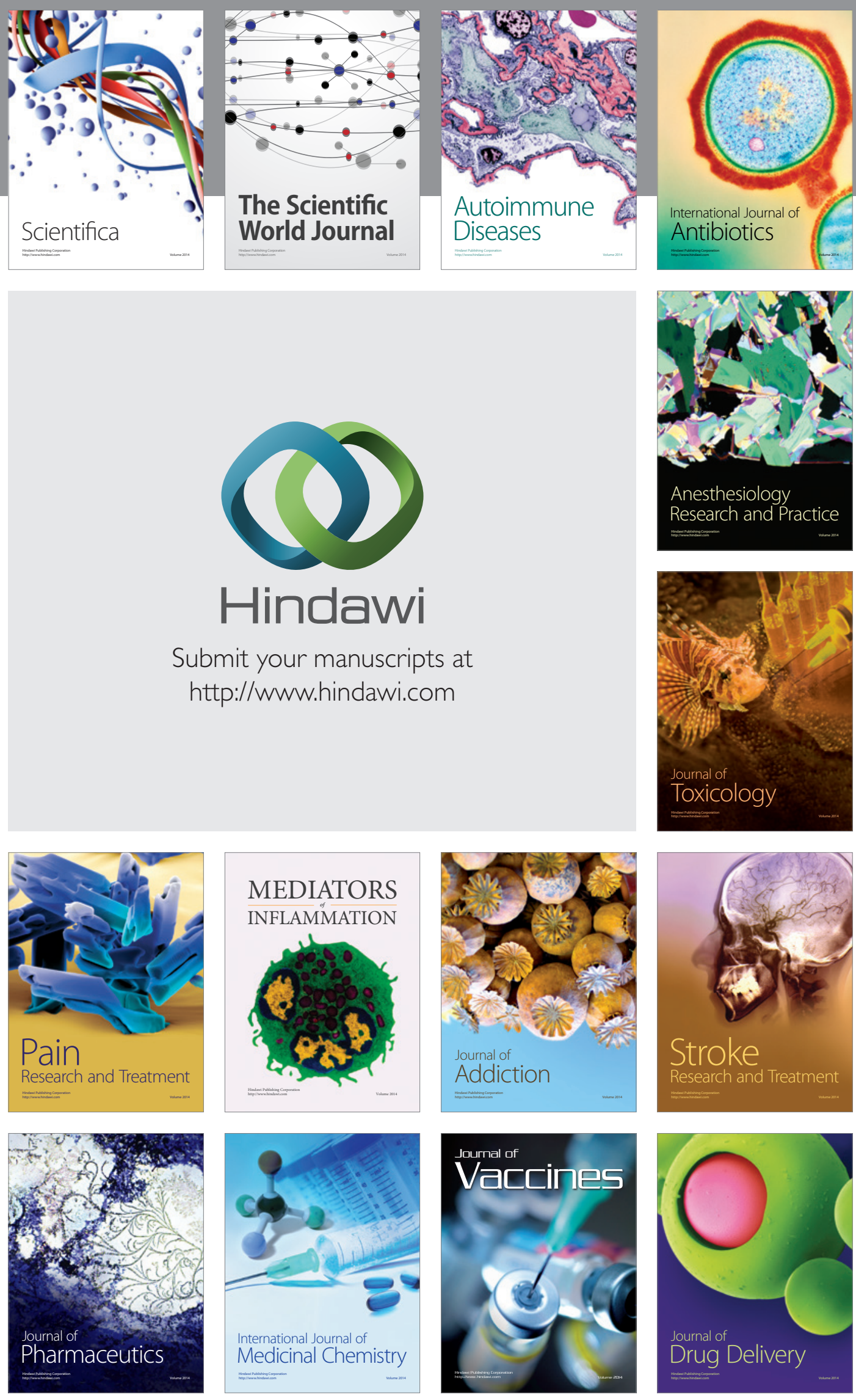